\title{
GENETIC CONTROL OF MOSQUITOES: POPULATION SUPPRESSION STRATEGIES
}

\author{
André Barretto Bruno WILKE \& Mauro Toledo MARRELLI
}

\begin{abstract}
SUMMARY
Over the last two decades, morbidity and mortality from malaria and dengue fever among other pathogens are an increasing Public Health problem. The increase in the geographic distribution of vectors is accompanied by the emergence of viruses and diseases in new areas. There are insufficient specific therapeutic drugs available and there are no reliable vaccines for malaria or dengue, although some progress has been achieved, there is still a long way between its development and actual field use. Most mosquito control measures have failed to achieve their goals, mostly because of the mosquito's great reproductive capacity and genomic flexibility. Chemical control is increasingly restricted due to potential human toxicity, mortality in no target organisms, insecticide resistance, and other environmental impacts. Other strategies for mosquito control are desperately needed. The Sterile Insect Technique (SIT) is a species-specific and environmentally benign method for insect population suppression, it is based on mass rearing, radiation mediated sterilization, and release of a large number of male insects. Releasing of Insects carrying a dominant lethal gene (RIDL) offers a solution to many of the drawbacks of traditional SIT that have limited its application in mosquitoes while maintaining its environmentally friendly and species-specific utility. The self-limiting nature of sterile mosquitoes tends to make the issues related to field use of these somewhat less challenging than for self-spreading systems characteristic of population replacement strategies. They also are closer to field use, so might be appropriate to consider first. The prospect of genetic control methods against mosquito vectored human diseases is rapidly becoming a reality, many decisions will need to be made on a national, regional and international level regarding the biosafety, social, cultural and ethical aspects of the use and deployment of these vector control methods.
\end{abstract}

KEYWORDS: Mosquito; Genetic control; SIT; RIDL; Field tests.

\section{INTRODUCTION}

Arthropods act as vectors for many human agents that cause several disease ${ }^{30}$. Over the last two decades, morbidity and mortality from malaria, dengue fever, West Nile Virus among other pathogens are an increasing Public Health problem. Malaria has been increasing due to deteriorating health systems, increased mosquito resistance to insecticides, parasite resistance to anti-malaria drugs and slow progress in vaccine development ${ }^{28}$. In 2008 malaria was endemic in 109 countries and almost 3.3 billion people were at risk worldwide. It is estimated that in 2008 there were 863,000 deaths from about 243 million cases ${ }^{40}$. Dengue fever, including dengue hemorrhagic fever and dengue shock syndrome, is a rapidly emerging arthropod-borne viral disease threatening one-third of the world's population with an estimated 50-100 million new infections per year ${ }^{13,18,33,41}$. Aedes aegypti, the main dengue vector, is an invasive species spread inadvertently around the world by human trade and travel and it is now distributed widely in tropical and subtropical regions, most notably in urban environments where it has adapted to breed in artificial containers and refuse. Finding and treating sufficient numbers of mosquito breeding sites as a measure of control is extremely challenging or impossible even for the most well-funded and organized programs.

The increase in the geographic distribution of vectors is accompanied by the emergence of viruses and diseases in new areas. There is currently no vaccine or specific therapeutic drug available for dengue; therefore, control focuses on the mosquito. Bed nets are largely ineffective against this day biting mosquito, making source reduction and space spraying the mainstays of control. New approaches and vector control tools are urgently needed ${ }^{11,24,26,31,39}$.

Mosquito control measures have failed to achieve their goals, mostly because of the mosquito's great reproductive capacity and genomic flexibility ${ }^{36}$. These two characteristics are exemplified by two observations. First of all, mosquito and other insects are well-known for developing resistance to insecticides and its resistance has been reported in most major insect disease vectors and against every class of chemical insecticide and insecticidal crops $\mathrm{s}^{30,34}$, and chemical control is increasingly restricted due to potential human toxicity, mortality in no target organisms, insecticide resistance, and other environmental 
impacts $^{22,37}$. The second is the existence of a variety of closely related species that form complexes of cryptic species, some of which seem to be undergoing speciation in the process of adapting to an environment modified by $\operatorname{man}^{10}$. Resistance to insecticides has led to serious mosquito control problems, contributing to the resurgence of mosquito-borne diseases.

In light of this type of problem, other strategies for mosquito control must be considered, including genetic control (use of sterile mosquitoes and related techniques). The sterile insect technique is a species-specific, effective and environmentally friendly technique of insect control that has been widely used, and has succeeded in controlling agricultural pests and, in certain cases, mosquito vectors ${ }^{12,35,42}$. The aim of this review is to revisit strategies of SIT-based genetic control of mosquito populations and the recent advances in molecular biology and field tests that promise to control vectored diseases.

\section{STERILE INSECT TECHNIQUE (SIT)}

The Sterile Insect Technique (SIT) is a species-specific and environmentally benign method for insect population control ${ }^{24,32}$. In 1955 , KNIPLING proposed the concept of introducing sterile insects into the population as a form of controlling pests with agricultural importance. SIT is based on mass rearing, radiation mediated sterilization, and release of a large number of male insects into a given target area $^{33}$ (Fig. 1). Any successful mating with the sterile insect will result in no offspring. If enough sterile insects are released the population will decline ${ }^{24,43}$. Reduction or elimination of vector populations will tend to reduce or eliminate transmission of vector-borne diseases and has been an effective method of disease control in many regions ${ }^{31}$.

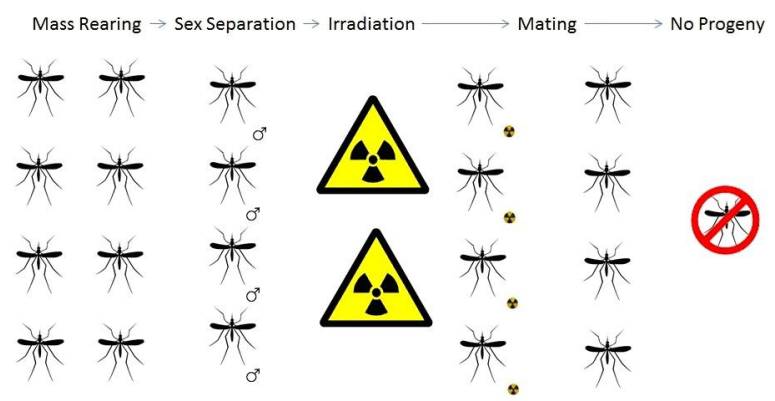

Fig. 1 - Conventional SIT schedule: mass rearing of mosquitoes followed by manual sex separation to assure that exclusively males are to be sterilized by ionizing radiation and further released to mate with wild females resulting in no progeny. This procedure must be repeated each and every time.

One of the major advantages of SIT over other techniques, such as insecticides, larvicides, and breeding site removal is that the males are very good at seeking out females of the same species and the technique becomes more effective as the population is reduced ${ }^{3,5,42}$. The Sterile Insect Technique is amongst the most non-disruptive pest control methods. Unlike some other biologically-based methods, it is species specific, does not release exotic agents into new environments and does not even introduce new genetic material into existing populations as the released organisms are not self-replicating ${ }^{21}$. The paradigm for this methodology was the successful elimination of Cochliomyia hominivorax (the causing agent of myiasis) from Southern United States, Mexico, and Central America. This area is currently protected from reinvasion from South-American flies by means of a barrier in Panama consisting of only a few sterile flies.

\section{SIT ISSUES}

A major difficulty with SIT as currently practiced is that the released sterile insects are required to compete for mates with wild insects ${ }^{8}$. The production process, however, and in particular the need to sterilize the insects by irradiation, causes a dramatic loss of competitive mating ability relative to wild type $\mathrm{e}^{5,27}$. The magnitude of this problem varies from one species to another but the combination of these effects leads to a tenfold or greater reduction in effectiveness for some species ${ }^{1}$.

Another problem is that SIT relies on the release of large numbers of sterile insects, but in some cases the adult females may themselves be unwanted or even hazardous. Mass rearing facilities initially produce equal numbers of the two sexes, but generally try to separate and discard females before release ${ }^{5,15}$.

Due to the possibility of preferential mating between released sterile insects and the fact that released sterile females do not diminish populations, bisexual releases are far less effective and more expensive than male-only releases in introducing sterility into wild populations. For agricultural pests in which females cause no damage, sex separation systems are not essential, but highly desirable in terms of increased efficiency. For the early SIT programs for mosquitoes, especially Aedes aegypti, sexes were separated using differences in pupal size, principally to increase efficiency. Since released sterile females may repeatedly feed on humans and thus contribute to disease transmission, tolerance for females in releases by programs targeting vector species is likely to be much lower than for agricultural pests. For these vectors, SIT can, therefore, only be applied if some highly efficient way to exclude females is developed. It is surprising that, in the earliest comprehensive description of SIT against mosquito vectors, developing sex separation methods is given almost no mention. Several inventive methods for sex separation of mosquitoes based solely on naturally occurring biological differences between males and females have been used. These have had varying degrees of success and were implemented at different scales.

Highly successful, area-wide SIT programs have eliminated or suppressed a range of major veterinary and agricultural pests around the world. These programs can succeed on very large scales - the largest rearing facility alone produces around two billion sterile male Mediterranean fruit flies per week ( 20 tons/week), primarily for use in California and Guatemala. For these pests, SIT is a proven, cost-effective strategy for eradication or suppression of target populations, or to protect areas against invasion or re-invasion.

For mosquitoes, the situation is much different, with variable successes and problems. About 20 field trials during the 1970s and 1980s demonstrated that the SIT could also be made to work against mosquitoes $^{10,23}$. For example, Anopheles albimanus was successfully controlled in a field trial in El Salvador, using chemo-sterilized mosquitoes ${ }^{25}$. The fundamental properties of SIT are still highly attractive for mosquito control. This has led to a resurgence of interest in recent years, with several research groups trying to circumvent some of the technical limitations which prevented conventional SIT from becoming 
a widespread approach following the early trials.

The use of SIT against mosquitoes is problematic, due mainly to the fitness costs and operational difficulty of irradiation, and the densitydependent nature of the target mosquito populations ${ }^{4,31}$. Distribution of mosquitoes may also be more problematic than for current SIT target species, for example, Ceratitis capitata (Medfly) and Cochliomyia hominivorax (New World Screwworm), because adult mosquitoes are less robust and more likely to suffer damage during transit and release $\mathrm{e}^{3,32,38}$.

\section{IMPROVING SIT: THE RIDL SYSTEM}

It is clear that an effective Genetic System Mechanism (GSM) would reduce the cost and increase the efficiency of a SIT program. Various female-killing and sex-sorting genetic systems have been developed. So far, all the GSMs brought into use in factory mass production have relied on the linking of a dominant selectable marker to the male determining chromosome ${ }^{5}$. These issues could be mitigated by the use of insects engineered to carry specific unique traits, including conditional genetic sterilization or lethality that removes the need for irradiation ${ }^{15}$. The ability to use recombinant DNA to molecularly engineer insects opens the door to a wide array of techniques to control pests and improve beneficial species and, in particular, create strains to improve biocontrol methods such as the sterile insect technique (SIT) ${ }^{19}$.

The RIDL (Release of Insects Carrying a Dominant Lethal Gene) system proposed by THOMAS et al. (2000) consists of introducing a lethal dominant gene that could be under control of a female-specific promoter, such as that of vitellogenin gene. Expression of the lethal gene could be inactivated by treatment with tetracycline, allowing a colony to be maintained. When male and female separation is required, tetracycline is removed from the system, causing the death of all females (Fig. 2). The RIDL system is centered on the expression of tTA, a fusion protein that combines sequence-specific tetracycline-repressible binding to tRe, a tetracycline-response element, to a eukaryotic transcriptional activator. In the absence of tetracycline, this protein will bind to the tRe sequence, activating transcription from a nearby minimal promoter ${ }^{5}$ (Fig. 2).

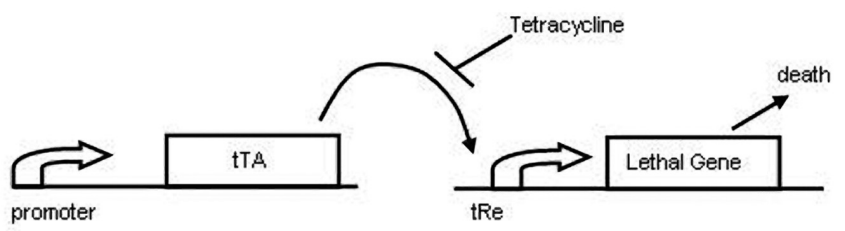

Fig. 2 - tTA and the tetracycline-repressible expression system. The tetracycline-repressible transcriptional activator (tTA) protein is placed under a promoter control. When expressed, the tTA protein binds to a specific DNA sequence, tetO, driving expression from an adjacent minimal promoter which leads to expression of any sequence (the effector gene) placed under the control of this minimal promoter. The combined effect is that the effector gene is expressed in essentially the pattern of the promoter driving tTA. However, in the presence of low concentrations of tetracycline, the tTA protein does not bind DNA and so expression of the effector gene is prevented. (Modified from ALPHEY 2002) 5

When preparing mosquitoes for release, the repressor is inactivated and the lethal gene is expressed, causing the death of all females. When mating with wild females, males homozygous for the lethal gene will produce heterozygous progenies, of which only males will survive. Releasing of Insects carrying a Dominant Lethal gene (RIDL technology) offers a solution to many of the drawbacks of traditional SIT that have limited its application in mosquitoes while maintaining its environmentally friendly and species-specific utility ${ }^{4}$. Transgenic males are homozygous for a dominant lethal gene. Mating with indigenous population results in offspring that are heterozygous for the lethal gene leading to the death of all females and hence eventual suppression of the population due to a decrease in its reproductive capacity (Fig. 3) 20,38. Genetic control aims to achieve universal coverage by taking advantage of the male insect's efficiency in locating and mating with females of the same species $^{44}$.

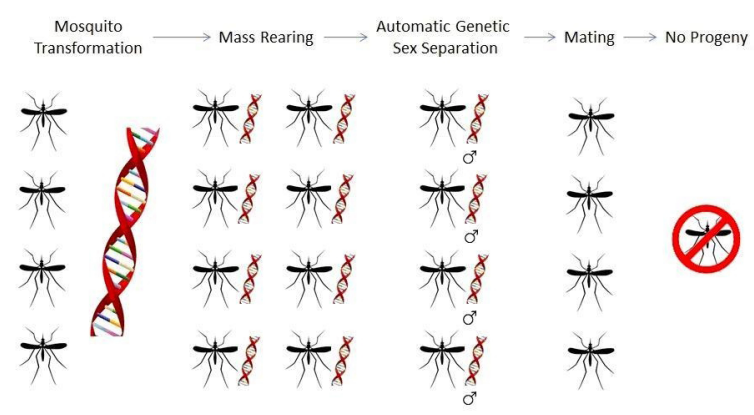

Fig. 3 - RIDL system: once a stable strain of genetic modified mosquitoes with female specific lethal gene is obtained, all that is need is to mass rear and remove the genetic repressor (tetracycline), the lethal gene will kill all females leaving males ready to be released and mate with wild females.

Insects engineered to carry a female-specific lethal (or otherwise incapacitating) gene could be used to remove females prior to release $\mathrm{s}^{3,14,23,38}$. A system based on a lethal gene (RIDL) $)^{38}$ that acts late in development would prevent mosquitoes from becoming adults, the only harmful life stage, yet enable them to survive and compete at the larval stage, when density-dependent competition occurs. Modeling this system predicts that fewer male mosquitoes of a late-lethal strain need to be released as compared to those carrying an early-lethal gene or irradiated strain to achieve an equivalent level of control of a target population $^{7,14,16,17,32,38}$.

A female-lethal version of RIDL, with insects homozygous for one or more female-specific dominant lethal genetic constructs, has been constructed in several species ${ }^{14}$. F1 progeny of RIDL males and wild females inherit a dominant female-specific lethal gene; the F1 females die, thereby reducing the reproductive potential of the wild population, but the F1 males are viable and fertile. This provides a genetic sexing mechanism facilitating male only release, either by employing the female-lethal version of RIDL and withdrawing the repressor from the generation prior to release, or by combining a bisex-lethal system with female lethality (with an independent means of repressing or inducing lethality) to permit male only release of bisex-lethal strains designed to kill progeny of both sexes in the field (Fig. 3$)^{5}$.

\section{ECONOMIC DEPENDENCE}

Economic cost-benefit analysis, which is needed to support use of novel interventions, is difficult because of lack of reliable data on the economic burden of disease for dengue and other neglected tropical diseases, and because of uncertainty around development and 
implementation costs. Ideally it would be possible to analyze not only the cost-effectiveness of the stand-alone novel strategy, but also to compare it with existing alternatives and to model its incorporation in integrated vector management (IVM) programs, and indeed integrated disease management programs including drugs and vaccines, where available ${ }^{40}$.

\section{RIDL FIELD TESTS}

Several different genetic approaches to mosquito control are being developed. These include approaches that are: Self-Limiting - repeated or recurrent releases are necessary to maintain the genetic construct in the target population. To have a significant epidemiological effect it will usually be necessary to release relatively large numbers of mosquitoes (inundative releases). Self-Sustaining - releases need to occur only once or a few times, and the construct will increase in frequency of its own accord and maintain itself at high frequency. Releases can often be of relatively fewer mosquitoes (inoculative releases) ${ }^{40}$.

As genetics-based population suppression (self-limiting) moves from laboratory to field, the lack of a clear regulatory framework for field use of modified mosquitoes is a significant challenge. This issue is not restricted to developing countries, or to strategies dependent on the use of recombinant DNA technology. Once regulatory frameworks are in place, risk assessments and public consultation also will be lengthy processes due the novelty of technologies and lack of experience by regulating agencies. The route to implementation of control programs based on these technologies is not obvious ${ }^{40}$.

Some issues must be fulfilled before a large scale mosquito release: (a) adult males must be known to mate with wild females at the release site, since laboratory cage fitness and competitiveness experiments of males does not ensure mating with wild type females; (b) sex separation lines improve efficiency and the effect of releasing programs, and are essential for mosquito vectors; (c) releasing methods must be suitable for all weather conditions anticipated, and are established and tested before control release programs start; (d) while female sterility provides an indicator of mating frequency, vector density is a more relevant indicator of the control effect on disease transmission; (e) mass rearing levels must be stable before releases begin; (f) releases must be programmed for maximum effect into suppressed populations; (g) wide control areas with similar monitoring must be available for comparison during suppression strategies development; (h) dispersion and mating characteristics are essential factors for quality control to assess the fitness of release material; (i) isolation of the test areas must be conducted and demonstrated conclusively for all weather conditions reasonably expected; ( $\mathrm{j}$ ) independent monitoring is essential to demonstrate effectiveness before release programs; (k) political stability, and healthy relationships with the public, press and political entities are essential for sustainability of control efforts ${ }^{10}$.

The self-limiting nature of sterile insects (whether sterilized by radiation, Wolbachia/CI (IIT), or RIDL genetic engineering) tends to make the issues related to field use of these somewhat less challenging than for self-spreading systems characteristic of population replacement strategies (including Wolbachia - and gene driver-based replacement strategies). They are also closer to field use, so might be appropriate to consider first. WHO/TDR funding for capacity-building and guidance development and this technical consultation are all steps in the right direction ${ }^{40}$.

There have been significant advances in population method using strains of Aedes aegypti homozygous for a dominant lethal genetic system $^{1,5}$. Efficacy testing of RIDL strains has already been carried out in laboratory and/or contained "semi-field" conditions in Brazil, Malaysia, Mexico and Cayman Islands 9 .

Under an envisioned RIDL release program, it would be important to detect any resistance in the pest population that was capable of having a significant detrimental impact on the program's effectiveness in time to take remedial action. Our population dynamic models predict a clear change in the pattern of pest as such resistance begins to spread. A properly designed monitoring strategy would be alert to such changes. Wild-caught individuals could then be used to screen for cross-resistance against a panel of available RIDL strains that use different lethal mechanisms, so that operations (or further trials, if this occurred before full implementation) could switch to deploying an appropriate alternative RIDL line before significant lasting loss of efficacy could result ${ }^{2,7}$.

\section{PERSPECTIVES}

The prospect of genetic control methods against mosquito vectored human diseases is rapidly approaching a reality. With the potential of a promising additional method for dengue and or malaria disease control, many decisions will need to be made on a national, regional and international level regarding the biosafety, social, cultural and ethical aspects of the use and deployment of these vector control methods.

A potential concern about releasing GM insects into the wild is that the inserted DNA may have unforeseen consequences. This has particularly been raised regarding strategies that aim to replace a wild population, for example with a version engineered to be unable to transmit a pathogen. One advantage claimed for genetic SIT strategies over population replacement strategies is that autocidal engineered insects are programmed to die and therefore the lethal genetic construct should die out if releases cease. This relies on the construct having some fitness costs even if it does not retain its efficacy. It has been shown that resistance to the construct might significantly increase its frequency.

In theory, there are combinations of genetic properties of resistance for which the construct could eventually be driven to fixation; that scenario is highly unlikely to be played out in real life because the release program could be stopped if substantial resistance were detected, long before the RIDL construct became common, and the wild type would reinvade through immigration ${ }^{6}$.

Endemic disease countries need international guidance to assess the risks and benefits of using genetically modified mosquitoes. Since they may reach different conclusions about using these mosquitoes the World Health Organization (WHO) and its partners are in process to provide best practice guidance to the endemic countries on these issues (Mosqguide) ${ }^{29}$. Communicating mosquito and disease biology, and risks and benefits associated with specific novel control strategies, is resource intensive and has no obvious endpoint ${ }^{40}$. 


\section{RESUMO}

\section{Controle genético de mosquitos: estratégias de supressão de populações}

Ao longo das duas últimas décadas, morbidade e mortalidade da malária e dengue e outros patógenos tem se tornado cada vez mais um problema de Saúde Pública. O aumento na distribuição geográfica de seus respectivos vetores é acompanhada pela emergência de doenças em novas áreas. Não estão disponíveis drogas específicas suficientes e não há vacinas específicas para imunizar as populações alvo. As medidas de controle de mosquitos atuais falharam em atingir os objetivos propostos, principalmente devido à grande capacidade reprodutiva dos mosquitos e alta flexibilidade genômica. O controle químico se torna cada vez mais restrito devido a sua potencial toxicidade aos seres humanos, mortalidade de organismos não alvos, resistência a inseticida além de outros impactos ambientais. Novas estratégias de controle são necessárias. A técnica do inseto estéril (SIT) é um método de supressão populacional espécie específico e ambientalmente amigável, baseia-se na criação em massa, esterilização mediante irradiação e liberação de um grande número de insetos machos. Liberar insetos carregando um gene letal dominante (RIDL) oferece uma solução a muitas limitações impostas pela técnica do inseto estéril (SIT) que limitaram sua aplicação em mosquitos e ainda assim mantém suas características de ambientalmente amigável e espécie específica. A natureza auto-limitante de mosquitos estéreis tende a deixar alguns empecilhos para uso no campo, de certa forma, menos desafiadores quando comparados a sistemas auto-propagação, característicos de estratégias de substituição de população. Sistemas auto-limitantes estão mais próximos para uso no campo, portanto pode ser apropriado considerá-lo primeiro. A perspectiva de métodos de controle genéticos contra mosquitos vetores de doenças que acometem humanos está rapidamente se tornando uma realidade, muitas decisões terão de ser tomadas em âmbito nacional, regional e internacional com relação a aspectos étnicos, sociais, culturais e de biossegurança para o uso e liberação destes métodos de controle de vetores.

\section{ACKNOWLEDGMENTS}

The authors would like to thank FAPESP for the financial support to MTM and MLC laboratory. ABBW is fellow of FAPESP.

\section{REFERENCES}

1. Alphey L, Andreasen M. Dominant lethality and insect population control. Mol Biochem Parasitol. 2002;121:173-8.

2. Alphey N, Bonsall MB, Alphey L. Modeling resistance to genetic control of insects. J Theor Biol. 2011;270:42-55.

3. Alphey L, Nimmo D, O'Connell S, Alphey N. Transgenesis and the management of vector-borne disease. In: Aksoy S, editor. Austin: Landes Bioscience; 2007. p 93-103.

4. Alphey L. Engineering insects for the Sterile Insect Technique. In: Vreysen M, Robinson A, Hendrichs J, editors. Area-wide control of insect pests: from research to field implementation. Dordrecht: Springer; 2007. p 51-60.

5. Alphey L. Re-engineering the sterile insect technique. Insect Biochem Mol Biol. 2002;32:1243-7.

6. Alphey L, Benedict M, Bellini R, Clark GG, Dame DA, Service MW, et al. Sterile-insect methods for control of mosquito-borne diseases: an analysis. Vector Borne Zoonotic Dis. 2010;10:295-311.
7. Atkinson MP, Su Z, Alphey N, Alphey LS, Coleman PG, Wein LM. Analyzing the control of mosquito-borne diseases by a dominant lethal genetic system. Proc Natl Acad Sci USA. 2007;104:9540-5.

8. Atkinson PW, Michel K. What's buzzing? Mosquito genomics and transgenic mosquitoes. Genesis. 2002;32:42-8.

9. Beech CJ, Quinlan MM, Capurro ML, Alphey LS, Mumford JD. Update: deployment of innovative genetic vector control strategies including an update on the MosqGuide Project. AsPac J Mol Biol Biotechnol. 2011;19:101-6.

10. Benedict MQ, Robinson AS. The first releases of transgenic mosquitoes: an argument for the sterile insect technique. Trends Parasitol. 2003;19:349-55.

11. Besansky NJ, Collins FH. The mosquito genome: organization, evolution and manipulation. Parasitol Today. 1992;8:186-92.

12. Bushland RC, Lindquist AW, Knipling EF. Eradication of screw-worms through release of sterilized males. Science. 1955;122:287-8

13. Dorta DM, Vasukai V, Rajavel A. Evaluation of organophosphorus and synthetic pyrethroid insecticides against six vector mosquito species. Rev Saude Publica. 1993;27:391-7.

14. Fu G, Condon KC, Epton MJ, Gong P, Jin L, Condon GC, et al. Female-specific insect lethality engineered using alternative splicing. Nat Biotechnol. 2007;25:353-7.

15. Fu G, Lees RS, Nimmo D, Aw D, Jin L, Gray P, et al. Female-specific flightless phenotype for mosquito control. Proc Natl Acad Sci USA. 2010;107:4550-4.

16. Gong P, Epton MJ, Fu G, Scaife S, Hiscox A, Condon KC, et al. A dominant lethal genetic system for autocidal control of the Mediterranean fruitfly. Nat Biotechnol. 2005;23:453-6.

17. Gossen M, Bujard H. Tight control of gene expression in mammalian cells by tetracyclineresponsive promoters. Proc Natl Acad Sci USA. 1992;89:5547-51.

18. Gubler DJ. The changing epidemiology of yellow fever and dengue, 1900 to 2003: full circle? Comp Immunol Microbiol Infect Dis. 2004;27:319-30.

19. Handler AM. Prospects for using genetic transformation for improved SIT and new biocontrol methods. Genetica. 2002;116:137-49.

20. Heinrich JL, Scott MJ. A repressible female-specific lethal genetic system for making transgenic insect strains suitable for a sterile-release program. Proc Natl Acad Sci USA. 2000;97:8229-32.

21. Hendrichs J, Robinson AS, Cayol JP, Enkerlin W. Medfly areawide sterile insect technique programmes for prevention, suppression or eradication: the importance of mating behavior studies. Florida Entomol. 2002;85:1-13.

22. Hood-Nowotny R, Mayr L, Knols BG. Use of carbon-13 as a population marker for Anopheles arabiensis in a sterile insect technique (SIT) context. Malar J. 2006;30:5-6.

23. Klassen W, Curtis CF. History of the sterile insect technique. Sterile Insect Technique. In: Dyck VA, Hendrichs J, Robinson AS, editors. Principles and practice in area-wide integrated pest management. Dordrecht: Springer; 2005. p 3-36.

24. Knipling E. Possibilities of insect control or eradication through use of sexually sterile males. J Econ Entomol. 1955;48:459-62.

25. Lofgren CS, Dame DA, Breeland SG, Weidhaas DE, Jeffery G, Kaiser R, et al. Release of chemosterilized males for the control of Anopheles albimanus in El Salvador. 3. Field methods and population control. Am J Trop Med Hyg. 1974;23:288-97.

26. Mackenzie JS, Gubler DJ, Petersen LR. Emerging flaviviruses: the spread and resurgence of Japanese encephalitis, West Nile and dengue virus. Nat Med. 2004;10(12 Suppl):S98-S109.

27. Marrelli MT, Moreira CK, Kelly D, Alphey L, Jacobs-Lorena M. Mosquito transgenesis: what is the fitness cost? Trends Parasitol. 2006;22:197-202. 
28. Moreira LA, Ghosh AK, Abraham EG, Jacobs-Lorena M. Genetic transformation of mosquitoes: a quest for malaria control. Int J Parasitol. 2002;32:1599-605.

29. Mumford J, Quilan MM, Beech CJ, Alphey L, Bayard V, Capurro ML, et al. MosqGuide: a project to develop best practice guidance for the deployment of innovative genetic vector control strategies for malaria and dengue. AsPac J Mol Biol Biotechnol. 2009; $17: 93-5$.

30. Nicholson GM. Fighting the global pest problem: preface to the special toxicon issue on insecticidal toxins and their potential for insect pest control. Toxicon. 2007;49:413-22.

31. Pates H, Curtis CF. Mosquito behavior and vector control. Annu Rev Entomol. 2005;50:5370.

32. Phuc HK, Andreasen MH, Burton RS, Vass C, Epton MJ, Pape G, et al. Late-acting dominant lethal genetic systems and mosquito control. BMC Biol. 2007;5:11.

33. Reiter P. Oviposition, dispersal and survival in Aedes aegypti: implications for the efficacy of control strategies. Vector-Borne Zoonotic Dis. 2007;7:261-73.

34. Reynolds A. Why EPA thinks resistance monitoring for $B t$ crops has been important and where do we go from here. San Diego: Entomological Society of America Annual Meeting; 2007.

35. Robinson AS, Franz G, Atkinson PW. Insect transgenesis and its potential role in agriculture and human health. Insect Biochem Mol Biol. 2004;34:113-20.

36. Shearman DC. The evolution of sex determination systems in dipteran insects other than Drosophila. Genetica. 2002;116:25-43.
37. Teixeira CF, Augusto LG, Morata TC. Saúde auditiva de trabalhadores expostos a ruídos e inseticidas. Rev Saude Publica. 2003;37:417-23.

38. Thomas DD, Donnelly CA, Wood RJ, Alphey LS. Insect population control using a dominant, repressible, lethal genetic system. Science. 2000;287:2474-6.

39. Vreysen M, Robinson AS, Hendrichs J. Area-wide control of insect pests: from research to field implementation. In: Dyck VA, Hendrichs J, Robinson AS, editors. Dordrecht: Springer; 2007. p 325-61.

40. WHO/TDR. Planning meetings on Progress and Prospects for the Use of Genetically Modified Mosquitoes to Prevent Disease Transmission: Meeting 1. Technical Consultations on the Current Status and Planning for Future Development. Geneva, May 4-6, 2009.

41. WHO-TDR. Scientific Working Group Report on Dengue. Geneva: World Health Organization; 2006. [Report no. TDR/SWG/08].

42. Wilke AB, Nimmo DD, St John O, Kojin BB, Capurro ML, Marrelli MT. Mini-review: genetic enhancements to the sterile insect technique to control mosquito populations. AsPac J Mol Biol Biotechnol. 2009;17:65-74.

43. Wilke AB, Gomes AC, Natal D, Marrelli MT. Control of vector populations using genetically modified mosquitoes. Rev Saude Publica. 2009;43:869-74.

44. Wyss JH. Screwworm eradication in the Americas. Ann NY Acad Sci. 2000;916:186-93.

Received: 31 October 2011

Accepted: 17 May 2012 